\title{
The Importance of Information Literacy Lesson for Academic Honesty in High Schools
}

Ayşegül Aksaçlıoğlu Yazar

aksacli@bilkent.edu.tr

Master Degree, Hacettepe University Library Science Department, IDV Özel Bilkent Lisesi

\section{Introduction}

$\mathrm{T}$ The new generation students, emerging with the rapidly evolving technology and have different information seeking behaviors showing that the librarians need to revise their services. Students are faced with various difficulties in searching for information and accessing information, because of the rapid increase in number and type of the information sources and lack of information literary skills. Students need to learn research techniques in finding the necessary information through a big ocean of information (published, electronic, audio visual, web, social networks, phone etc.), and writing research papers appropriate for academic honesty and international standards framework. Students need to gain "Information Literacy Skills" to become lifelong individual learners so that they can choose research topic, create a research question properly in line with research objectives, access the different types of information resources, evaluate reliability of resources, select, quote relevant information, synthesize and present.

İhsan Doğramacı Foundation (IDF) Bilkent High School students studying in the National Program should prepare the "performance and project paper" within the scope of the National Ministry of Education regulations. Students studying the International Diploma Program are required to write the "Internal Assessment Studies, Essays, and 4000 word Extended Essay" within the scope of the International Baccaluarate Organization (IBO) rules. The role of the informaton literacy skills lessons supported by the teachers is very important. 
In this article, experience will be shared by emphasizing the cooperation of teacher and librarian in the process of preparation and presentation of information literacy courses given in IDF Bilkent High School within the scope of national and international programs.

Keywords: Academic Honesty, Information Literacy, IB Diploma Programme, National Programme, Library

\section{Statement of the Research Problem}

The continuing expansion of information has been increasing rapidly with the rapid technological change. Reliability of the information isn't clear so students need to have selection, evaluation and decision skills to access correct information. Environments where information is stored are diversified. In addition to publised resource, there are many different kinds of information sources such as online databeses, e-books, electronic journals, web tools, social networks, discussion groups etc. The quality of information on the web is uncertain. Since copying information from electronic sources is very easy, students usually prefer to copy and paste. Everybody has been publishing some information on the Web. Is the publisher/author auothorized? How can they decide the reliability and truth of the information taken from web. Accessing the source of information on the Web and determining the publisher are difficult. Students don't have enough information literacy skills and philosphy of the academic honesty.

With the developing technology, it is necessary for the students to have the necessary information literacy skills in order to be the life long learners. In this regard, there are various tasks for administrators, teachers and librarians. Collaboration of librarians and teachers has a key role in ensuring that students acquire information literacy skills through experiences during the project process, and in creating the awareness of academic honesty. The lessons given by the librarians and project-based studies with various branch teachers will help students to gain information literacy skills, understanding of academic honesty.

\section{Literature Review}

\section{Information Literacy}

In literatur, there are many information litearcy definition; ALA has defined as information literacy is a set of abilities requiring individuals to recognize when information is needed and have the ability to locate, evaluate, use effectively the needed information and communicate the information needed (ALA, 1989). Information literacy is the ability to search, evaluate, use 
and create knowledge effectively to ensure that individuals reach their personal, social, vocational and educational goals in every aspect of life (Alexandria Proclamation, 2005).

"Information literacy, the use of technology, critical thinking, and ethical decision making all have a basis in skills and an actualization in the behaviors that students choose to exhibit-from seeking diverse perspectives, to evaluating information, to using technology appropriately, to applying information literacy skills, to using multiple formats"( American Association of School Librarians, 2009)

Information literacy is an umberalla term that including set of ability and multiple literacy such as digital, visual, textual, and technological. In the light of these definitions, an student who has information literacy skills;

- is aware that information is very important,

- is aware of the type of information they need,

- knows where and how to find the information. Students can access the different kinds of information resource from school, university, public library and publisher. They can do catalog search and find the materials that they need in the selves.

- is able to select, evaluate and synthesize information from different sources according to their hypothesis, subjects and headings.

- uses existing information and produces new information.

- acts within the framework of academic honesty principles.

- is aware of the international writing standards like as MLA, APA, and Harvard.

- knows how to cite from different types of resources.

- has independent learning skills

- has information literacy

- is life-long learner

School librarians teach students how to be inquiring learners who evaluate and use both print and digital information efficiently, effectively, and ethically, with the goal of developing lifelong learning and literacy skills (AASL, 2007). IFLA School Library Guide is emphasized that school librarians should focus on the pedogagical activities which students provide information liteacy skills such as critical thinking, inquiry, technological integration and cooperate with teachers (2015, p.40). 


\section{Diploma Programme and Academic Honesty}

IB programmes is to aim raising students who has international minded, learning through expererience, aware of the humanity, planet, world and own community, became life-long learner skills, working to create a better and more peaceful world (What is an IB Education, 2015)

IB learner profile has ten characteristics which students strive to become are inquirers, knowledgeable, thinkers, communicators, principled, openminded, caring, risk-takers, balanced and reflective. Inquirers, caring, principled and knowleagable charactericstics has been directly related to library and academic honesty. These concepts is very important for information literacy. There are six group lessons in Diploma Programme. Students has taken $3 \mathrm{HL}$ and $3 \mathrm{SL}$ lesson in Bilkwent High School. In addition to these lesson students have to complete Theory of Knowledge, Extended Essay and CAS (Creativty-Action- Service) for obtaining the IB Diploma.

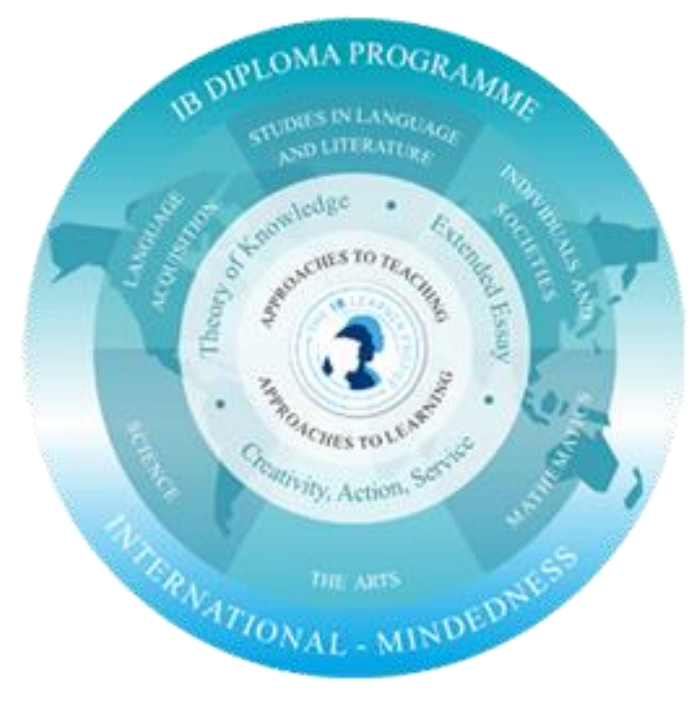

Fig. 1. Diploma Programme Cirriculum

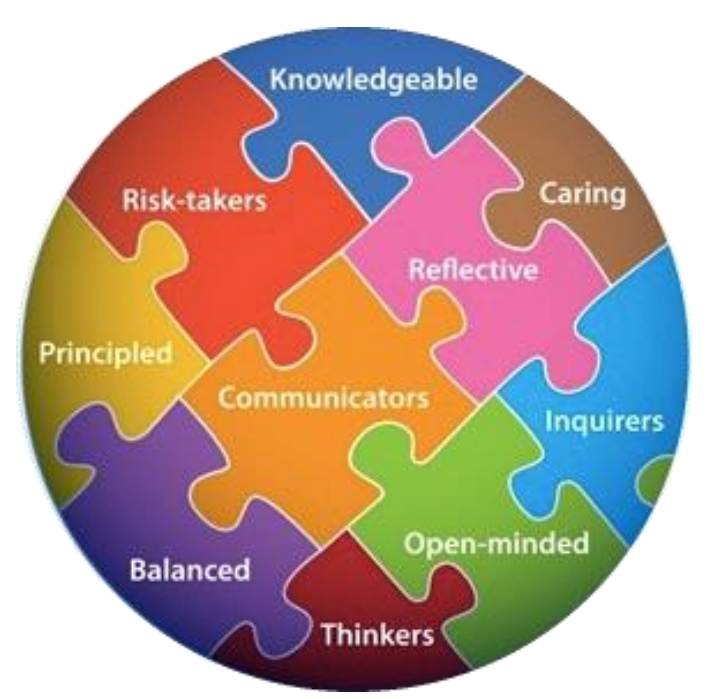

Fig.2. IB Learner Profile

Students have to do different kind of projects in order to graduate from national and IB programmes. Students in national programme have to prepare the minimum a performance assignment from all lesson in every semester and a project asssignment from a lesson that they will select during the year (Milli Eğitim Bakanlığı Orta Öğretim Kurumları Yönetmeliği[Ministry Education Secondary Schools Regulation], 2017, Item 50).

Students in Middle Years Programme have to prepare personel project and community service project (MYP: From principles into practice, 2014, p.6; MYP Projects, 2018; 10 Steps to 
Successful MYP Personal Projects, 2015) and students in Diploma Programme have to do Extended Essay, Internal Assesments, Essays, Studio Works, Exhibition, Essays according to lessons that they select.

Library and specialist librarians has very important role in IB learning profile and diploma programme curriculum. Librarian and teachers expect from students to become some skills during these research process following as;

$>$ creating a suitable hypothesis and research question,

$>$ accessing needed information sources by individual research,

$>$ understanding, analyzeing and synthesizing the information in various sources through reading, watching and hearing,

$>$ transfering the knowledge to your daily life.

$>$ improving the information literacy and lifelong learning skills.

Students have to be caring to academic honesty during all steps of the research process. IBO has often emphasized the importance of the academic honesty in their guides "Program Standards and Practices" in sections Standard C3 related to teaching and learning; "Teaching and learning promotes the understanding and practice of academic honesty" (Programme standards and practices, 2016, p. 5,12,19,25,32), Standard B1 related to leadership and structure; "The school has developed and implements an academic honesty policy that is consistent with IB expectations" (Programme standards and practices, 2016, p. 16, 22, 28). and B2 related to resource and support; "The library/multimedia/resources play a central role in the implementation of the programme(s) "( Programme standards and practices, 2016, p. $4,9,17,23)$. While teachers making unit plan and students preparing the projects, they need to be careful reference and academic honesty in criteria $\mathrm{C}$.

In guide called Academic honesty in the IB educational context published by IBO, "academic honesty is an essential aspect of teaching and learning in IB programmes ( and should be in national programme) where action is based on inquiry and reflection" (Academic Honesty , 2014, p. 2). Academic honesty can define as usage of information within the framework of ethical and legal rules. Teachers and students must act within the framework of the ethical and legal rules established by the IBO and IDF Bilkent High School. 


\section{Methodology}

Bilkent High School is established 1993 in Ankara, the capital city of Turkey. National Programme certificated by Ministry of National Education have been implementing since 1993. In addition to national programme, International Baccalaurate Diploma Programme (IB DP) authorized by IBO have been applying since 2008 .

Information Literacy Lesson in Bilkent High School to 9th grade students has been given one lesson per week between 18th September and 6th November 2017 by the school librarian, specialist Ayşegül Aksaçlıoğlu Yazar. There isn't any lesson called “Information Literacy Lesson" in the cirriculum. Librarian has been cooperate with Geography, Physical Education and Religion Teachers and used their lesson time with the approval of the school principal. During these lesson, subjects has been explained by using power point presentations, exercises, individual and group working. The contents of the lessons has been given below. All contents of the lesson was installed the Moodle for national students and ManageBac for international diploma programme students. 


\begin{tabular}{|c|c|}
\hline DATE & TOPICS \\
\hline $\begin{array}{l}\text { 18-22 } \\
\text { SEPTEMBER }\end{array}$ & $\begin{array}{l}\text { - Brain storming about "What is Academic Honesty"? } \\
\text { - What is the meaning of copyright, fair use and plagiarism? } \\
\text { - What is the intenionally and unintentionally plagiarism? } \\
\text { - What types of plagiarism are related to Web } 2.0 \text { tools? } \\
\text { - What should I pay attention in order to avoid plagiarism? }\end{array}$ \\
\hline $\begin{array}{l}25-29 \\
\text { SEPTEMBER }\end{array}$ & $\begin{array}{l}\text { - Librariay orientation. Library placement. Library services and rules. } \\
\text { - The types of the information resources. What kind of information resources are in our library? } \\
\text { - What is the catalogue? How we can search from catalogue? } \\
\text { - What is the classification system? What are the LC and Dewey Systems? } \\
\text { - What is the meaning of colour and labels on the shelves? }\end{array}$ \\
\hline $\begin{array}{c}\text { 02-06 } \\
\text { OCTOBER }\end{array}$ & $\begin{array}{l}\text { - Big Six Skills Model: What are the } 6 \text { steps to follow while researching? } \\
\text { - Choosing a topic, expanding and narrowing a topic of An assignment, using of 5N1K method to create main and sub-headings. } \\
\text { - What are the sections that should be in an assignment? An exercises. }\end{array}$ \\
\hline $\begin{array}{l}9-13 \\
\text { OCTOBER }\end{array}$ & $\begin{array}{l}\text { - What is the meaning of the international standars and MLA format? } \\
\text { - How should an assignment be written according to the seventh edition of the MLA? } \\
\text { - How to write the sources used in the assignment in the text? } \\
\text { - What are the meaning of quotation and paraphrasing? }\end{array}$ \\
\hline $\begin{array}{c}\text { 16-20 } \\
\text { OCTOBER }\end{array}$ & $\begin{array}{l}\text { - How to use visuals such as tables, graphics, pictures, charts, photos etc. in the text? } \\
\text { - How to show content and bibliographic footnotes? An exercise. }\end{array}$ \\
\hline $\begin{array}{c}\text { 23-27 } \\
\text { OCTOBER }\end{array}$ & $\begin{array}{l}\text { - How should the bibliography be prepared according to MLA? } \\
\text { - How can show the electronic resources such as an article, an e-book from database, pdf file from internet, e-mail, dvd etc. } \\
\text { - An exercise. }\end{array}$ \\
\hline $\begin{array}{c}\text { 30-3 } \\
\text { NOVEMBER }\end{array}$ & $\begin{array}{l}\text { - What are the tools(citation generators) to write a bibliography? (EasyBib, Son of Citation Machine, Mendeley etc.) } \\
\text { - An exercise. }\end{array}$ \\
\hline $\begin{array}{c}\text { 6-10 } \\
\text { NOVEMBER }\end{array}$ & $\begin{array}{l}\text { - What is a online database? } \\
\text { - How to search from the databases? How to choose a keyword? } \\
\text { - What are the Boolean operators? How should Boolean operators be used? } \\
\text { - An exercises. }\end{array}$ \\
\hline $\begin{array}{l}\text { 9-20 APRIL } \\
2018\end{array}$ & - Bilkent Universty Library Training \\
\hline
\end{tabular}




\section{Discussion}

\section{Implications and Conclusions}

It is important that school management, teachers, and librarians work together and collaborate gaining information literacy skills that student will use throughout their university, professional and social lives, and ensure to be life-long learner. In this context, some ideas related to information literacy in high school can be suggested as follows.

- Schools shoulds appreciate and integrate the concept of information literacy into their learning programs.

- The project and academic honesty expected from IB students should also be requested from students studying in the national program.

- School administration should support the information literacy lesson by librarian and allocate the required time for the librarian to the lesson.

- Librarian sould prepare the trainings and present related to academic honesty and information literacy if required.

- According to the dynamics of the school, there should be an academic honesty policy prepared by the cooperation of school administrations, teachers and librarians. School community act within this policy.

- The importance of the information literacy and definition and content of lesson should include under the part of instructional lesson/trainings/programme in the school library policy prepared by the librarian.

- Librarians should prepare and organized various pedogogical library activites cooperation with branch teachers to develop students information literacy skills.

- Teachers should put some criterias to their project evaluation rubric related to learning outcomes of information liteacy lesson and inform students about this subject.

- Librarian should prepare the documents and guide that include key information to make easy student's life such as catalogue search, online database search, Big Six Skill Steps, writing of project paper, quotation, paraphrasing and bibliography. All documents should be accessed from everywhere for school community. Students and teachers should access to all documents and guides from everywhere.

Through the lessons given to the ninth graders one hour a week for two months at the İhsan Doğramacı Foundation Bilkent High School; it can be told; 
- The view of the students and teachers to library and librarian has change postive way. The library became living center that students want to pass more time and ninth graders start to use library more effectively according to other grades.

- There is awareness about academic honesty in the ninth grader students, and this awareness is reflected in research habits.

- Students have the ability to do catalog searching and find the materials on the shelves individually.

- Students has started to use online database in their research.

- Students have became ability to evalute the realibity of information on web. When they will use the internet for their project, they prefer web pages which published by authorited people and associationStudents has started to use citation, paraphrasing in their project and to show bibliography in order to avoid plagiarism. If needed, they have wanted guiadance from librarian.

- The awareness about the international writing standards especially MLA was gained experience by students.

- More ninth grader students has wanted to be member of the Bilkent University Library and has started to use Bilkent University Library more effectively. 


\section{References}

Academic honesty in the IB educational context (2014). Geneva, Switzerland: IBO.

ALA-Americal Library Association (1989). Presidental Committee on Information Literacy. Association of College and Reseacrh Libraries. Accessed from: http://www.ala.org/acrl/publications/whitepapers/presidential

American Association of School Librarians. (2007) "Standards for the 21st Century Learner." AASL. www.ala.org/aasl/standards/learning

American Association of School Librarians (2009). Standards for the 21st-Century Learner in Action. E-book.

Beacons of the Information Society: The Alexandria Proclamation on Information Literacy and Lifelong Learning (2005). IFLA. Accesed from: https://www.ifla.org/publications/beacons-ofthe-information-society-the-alexandria-proclamation-on-information-literacy

Curriculum (2016). International Baccalaureate Organization. Web. 8 Agust 2016. <http://www.ibo.org/programmes/diploma-programme/curriculum/>

Eisenberg, M. B. and R. E. Berkowitz (1996). Helping with Homework: A Parent's Guide To Information Solving. New York : ERIC Clearinghouse, Information \& Technology Syracuse University.

Eisenberg, M. B. and R. E. Berkowitz (1990). Information Problem Solving: The Big Six Skills Approach To Library And Information Skills Instruction. Norwood: Ablex Pub.

Eisenberg, M. and R. W. Berkowitz (2017). "What is Big6". The Big 6 Information Technology Skills for Student Sucess. Accessed: http://big6.com/pages/about.php

Extended Essay Guide.(2016). Geneva, Switzerland: IBO.

Harmanc1, C. (2013). T.C Milli Eğitim Bakanlı̆̆ Özel Bilkent Lisesi Akademik Dürüstlük Rehberi. Ankara: Özel Bilkent Lisesi.

Information Literacy Competency Standards for Higher Education. ALA. Accessed from:

http://www.ala.org/Template.cfm?Section=Home\&template=/ContentManagement/ContentDispl ay.cfm\&ContentID=33553

International Baccalaureate Middle Years Programme Subject Brief (2014). International Baccalaureate Organization. Accessed from: https://www.ibo.org/globalassets/digitaltookit/brochures/myp-brief_personal-project_2015.pdf

10 Steps to Successful MYP Personal Projects (2015). Geneva, Switzerland: IBO. Pdf File. 
Milli Eğitim Bakanlığı Orta Öğretim Kurumları Yönetmeliği [Ministry Education Secondary Schools Regulation] (2017, 16 Eylül). TC Milli Ĕ̆itim Bakanlı̆̆ Orta Öğretim Kurumları Web Sayfast. Accessed: http://ogm.meb.gov.tr/meb_iys_dosyalar/2017_09/20161748_MYLLY_EYYTYM_BAKANLIY I_ORTAYYRETYM_KURUMLARI_YYNETMELYYY.pdf

MYP: From principles into practice (2014). Geneva, Switzerland: IBO.

MYP Projects (2018). International Baccalaureate Organization. Accessed: https://www.ibo.org/programmes/middle-years-programme/curriculum/myp-projects/

Programme standards and practices (2016). Switzerland: IBO.PDF file.

What is an IB Education (2015). Geneva, Switzerland: IBO.

Yazar Aksaçlığlu, A. (2016). Akademik Dürüstlük Araştırma Rehberi. Ankara: Özel Bilkent Lisesi. 